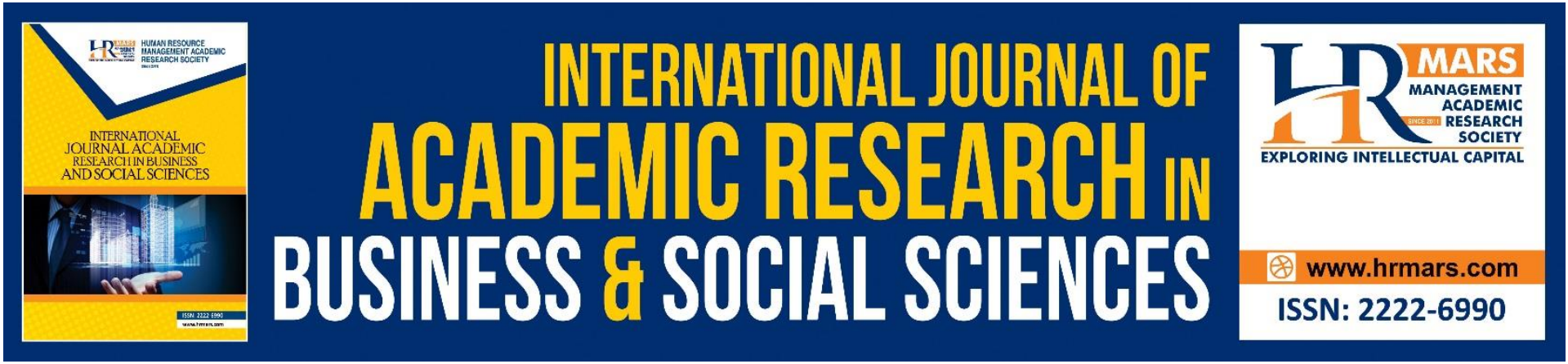

\title{
Equity Crowdfunding: Factors Influencing the Performance of Firm in Malaysia
}

Siti Fatimah Mohd Kassim, Kalsom Abd. Wahab, Nurul Aini Muhamed

To Link this Article: http://dx.doi.org/10.6007/IJARBSS/v10-i7/7600

DOI:10.6007/IJARBSS/v10-i7/7600

Received: 20 April 2020, Revised: 25 May 2020, Accepted: 21 June 2020

Published Online: 28 July 2020

In-Text Citation: (Kassim et al., 2020)

To Cite this Article: Kassim, S. F. M., Wahab, K. A., \& Muhamed, N. A. (2020). Equity Crowdfunding: Factors Influencing the Performance of Firm in Malaysia. International Journal of Academic Research in Business and Social Sciences, 10(7), 717-737.

Copyright: (C) 2020 The Author(s)

Published by Human Resource Management Academic Research Society (www.hrmars.com)

This article is published under the Creative Commons Attribution (CC BY 4.0) license. Anyone may reproduce, distribute, translate and create derivative works of this article (for both commercial and non-commercial purposes), subject to full attribution to the original publication and authors. The full terms of this license may be seen

at: http://creativecommons.org/licences/by/4.0/legalcode

Vol. 10, No. 7, 2020, Pg. 717 - 737

http://hrmars.com/index.php/pages/detail/IJARBSS

JOURNAL HOMEPAGE

Full Terms \& Conditions of access and use can be found at http://hrmars.com/index.php/pages/detail/publication-ethics 


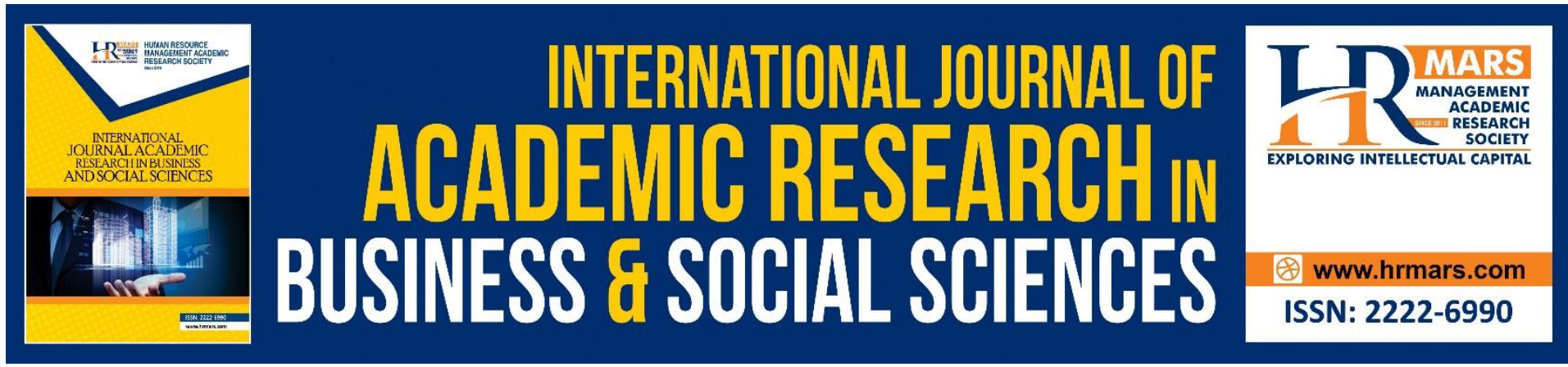

\title{
Equity Crowdfunding: Factors Influencing the Performance of Firm in Malaysia
}

\author{
Siti Fatimah Mohd Kassim¹, Kalsom Abd. Wahab², Nurul Aini \\ Muhamed ${ }^{3}$ \\ ${ }^{1} \mathrm{PhD}$ Candidate, Faculty of Muamalat and Economics, ${ }^{2,3}$ Faculty of Muamalat and \\ Economics, Universiti Sains Islam Malaysia, Bandar Baru Nilai, 71800, Negeri Sembilan, \\ Malaysia
}

\begin{abstract}
This study aims to investigate the factors that influence the performance of the firms funded by equity crowdfunding after the campaign ended successfully. The factors investigated are the top management team (TMT), social networks and the platform provider (PP). Not many studies discuss on the related variables on ECF ecosystem in Malaysia. As such, this study adopts conceptual research approach by examining and analysing previous literatures on the topic. This study will answer the following questions; i) How TMT, social networks and platform provider influence the performance of the ECF funded firm. The findings indicate that under crowdfunding ecosystem, the characteristics of the founder and TMT play an important roles to attract the investors' attention. They form a strategic human assets in the firm. This implicitly signals the firm's values and reduce the asymmetry information. The values upsurge with the social traits among their networks. The networks can be among other those with more funding capability to inject more money when requested by the entrepreneur. Investors in crowfunding scenario invest based on closeness and trustworthiness. Thus, ECF funded firm with promising human capital, networks capital generated internally and externally as well as well known platform provider plus the workable business plan able to attract financial capital from investors when needed. The emergence of ECF fund and other new emergence financing instruments have evolved the entrepreneurial landscape worldwide. Moreover, these funding are unique as they can be tailored according to the firm funding objective. Nowadays, these type of funding have been widely used in real estate, agricultural and health industries too. The revolution in financial industry known as fintech is a plus to crowdfunding ecosystem. Despite of disrupting the traditional banking and financial institutions, crowdfunding provides opportunities to potential ventures with scarce capital resources. The uniqueness of this research is that previous studies yet to discuss how PP moderates the effect of founder, TMT and networks towards the ECF funded firm performance.
\end{abstract}

Keywords: Equity Crowdfunding, Top Management Team, Social Networks, Platform Provider, Information Asymmetry, Trust. 
INTERNATIONAL JOURNAL OF ACADEMIC RESEARCH IN BUSINESS AND SOCIAL SCIENCES

Vol. 10, No. 7, July, 2020, E-ISSN: 2222-6990 @ 2020 HRMARS

\section{Introduction}

Crowdfunding has evolved the entrepreneurial landscape worldwide. It has become a success alternative financing for start-ups and small and medium enterprises (SMEs) in developed and developing countries especially the equity crowdfunding (ECF). Mayorova and Petrenko (2018) explain that crowdfunding can be tailored according to the need of the entrepreneur's funding need. However, this study focuses on ECF in Malaysia. The phenomenon on ECF is relatively new in Malaysia. It is subjected to the rules as provided by the Regulation of Markets under Section 34 of the Capital Market and Services Act 2007. Due to its emergence as potential source of capital, entrepreneurs' involvement in ECF is still lower in Malaysia as compared to other countries.

Even though, ECF is not an absolute financing for the enterprises, it could be providing a jumpstart for the start-ups to accelerate their business plan and get public recognition on their product or service. However, there is a need to understand the features of crowdfunding available in the emerging financial market. This study investigates the founder and top management team (TMT) that are regarded as human capital of the firm, social networks and the credibility of the platform provider (PP) in accelerate the performance of the firm.

According to Storey (1994), the performance of the firm depends on three factors; the founder demography, firm demography and strategies practices in the firm. The ability of the firm's human capital to grab the opportunities in order to spur its performance as explained by the theory of finance bricolage. This ability leads to firm survival and sustainability. The strategies from various aspects such as the competence TMT, social networks and platform provider help in achieving desire results.

In the process of raising the fund, firstly, the firm launches the ECF campaign. Normally, it starts from the private pitching. The private pitching is done before the campaign actually launch on the platform. Then only, the campaign is launched on the platform provider's website for public pitching. At each of the stages, it signals to the stakeholders 'how is it' going on. This then captures the investors' attention and intention to participate. The more the investors participate the fastest and high chances the campaign will success.

The following sections and sub-sections discuss the features of crowdfunding and characteristics that influence the success of the campaign and thus effect the performance of the firm. Success in ECF funded firm can be categorize into two; success in raising crowdfunding fund and success in running the business. The information regarding the founder and his/her team are vital. The more transparent the firms about its founder and TMT qualities the less information asymmetry. Thus, increase the funder trust in the venture. Nowadays, the dynamic of entrepreneurial spectrum the investors to decide on funding based on trust. Even though, ECF fund is not an absolute financing for entrepreneurs, it could be providing a kick-start to progress or growth. In theory, adequate resources are important for a venture to progress for a better performance.

\section{Crowdfunding \\ Definition}

Crowdfunding is basically a small amount of money collected from a large pool of people using internet. It can involves an individual, institution, non-profit organisation, or company which convinces the crowd or a group of individuals of different education background, characters, and experiences through a flexible open call. It is the voluntary undertaking of a task which always entails 
INTERNATIONAL JOURNAL OF ACADEMIC RESEARCH IN BUSINESS AND SOCIAL SCIENCES

Vol. 10, No. 7, July, 2020, E-ISSN: 2222-6990 @ 2020 HRMARS

mutual benefit, and the crowd participates by bringing in work, money, knowledge, and experiences (Estellés-Arolas \& González-Ladrón-De-Guevara, 2012).

\section{Types of Crowdfunding}

Basically there four familiar types; donation, reward, equity and peer lending. However, the types of crowdfunding could evolve as it could be tailored according to the funding need of the entrepreneur (Mayorova \& Petrenko, 2018).

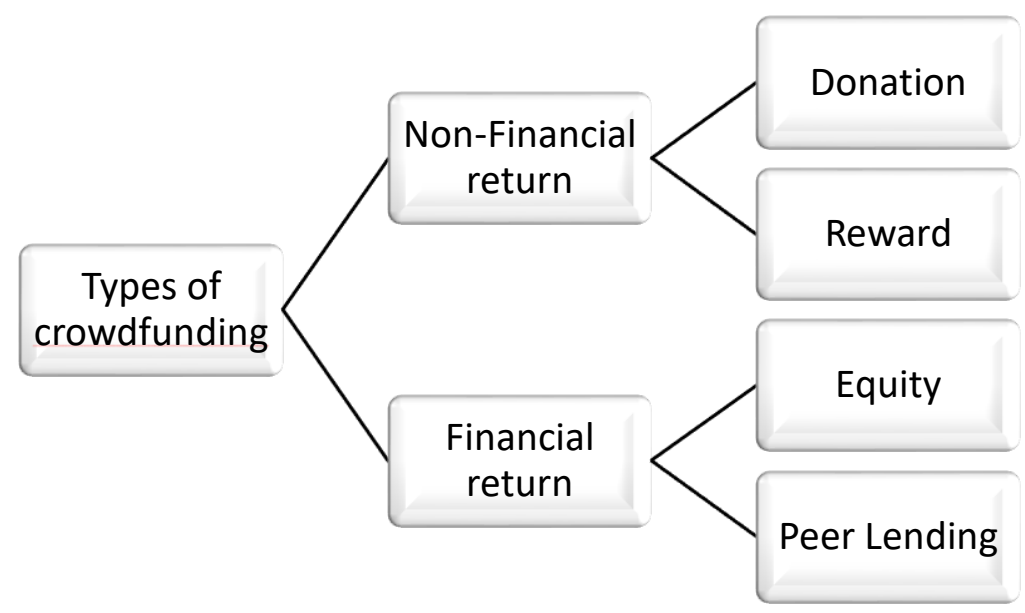

\section{Donation-based Crowdfunding}

Historically, crowdfunding started with the donation model (Meyskens \& Bird, 2015; Mollick, 2014). The main aim of donation crowdfunding is to collect money. Though sounding ordinary, what makes it different from the common donation is the interference of online mechanism (Kraus et al., 2016). Under this model, the donors participate because of the social value that triggers their spirit to invest and not for any material returns. This is the reason why social enterprises are familiar with the donation model where the core social value is most important rather than the reward or return (Kraus et al., 2016; Lehner, 2013). Hence, when the project is high in social value but low in economic value, the most suitable crowdfunding model is donation type. That is the reason why most charities and non-profit organisations prefer to engage with the donation model, and it has been proven that when it comes to social causes, events, or campaigns, people tend to act fast (Swart \& Milner, 2015). A study by Shepherd and Patzelt (2011) discovered that funding success in crowdfunding is influenced by the entrepreneur's orientation. An entrepreneur with a sustainability orientation that focused on social purposes' projects concerning the community, natural life care, and protection of Mother Nature has more chances to success in the crowdfunding campaign. This is because the gain arises from the venture with sustainability orientation taking account of individuals, the economy, and society economically and non-economically. As a consequence, the success factor in the donation model is an eye opener to some donors who may subsequently think that some appreciation would be nice and eventually develop rewards-based crowdfunding as another type of crowdfunding. 
INTERNATIONAL JOURNAL OF ACADEMIC RESEARCH IN BUSINESS AND SOCIAL SCIENCES Vol. 10, No. 7, July, 2020, E-ISSN: 2222-6990 @ 2020 HRMARS

\section{Reward-based Crowdfunding}

In this model, participating donors will be given a reward that matches the donation they have made in the crowdfunding event. The reward can be in the form of thanking mail, printed name on a t-shirt, or the donor's name in the project acknowledgment book (Hemer, 2011). There is also 'preselling' in which priority is given to the investor or 'early customer' who contributes to the preproduction of the product (Frydrych et al., 2014; Mollick, 2014). The nature of the investment serves both parties, the entrepreneur and the investors, where the entrepreneur receives the money for his/her product at the pre-order stage, and the investors have a chance to receive either material or immaterial rewards for the investments they make (Kraus et al., 2016). The purpose of the reward is not only to appreciate the investors' participation, but is also meant to encourage them to continue participation in the project (Swart \& Milner, 2015). However, the entrepreneur's sustainability orientation still plays an important role to ensure the target funding success. According to Calic and Mosakowski (2016), the entrepreneur's sustainability orientation and target funding success have a positive impact, as investors' motivation shifts from monetary returns to other forms of returns. Next is equity-based crowdfunding.

\section{Lending-based Crowdfunding}

Lending-based crowdfunding also known as Peer-to-peer (p2p) is a type of debt-based crowdfunding. Money is pulled in from individuals who advance money to others, other individuals or companies that are short of money to run the business (Kraus et al., 2016). It involves a group of people pooling their money as debts to entrepreneurial business start-ups or small businesses in return of interest. Here, $\mathrm{p} 2 \mathrm{p}$ bypasses banks and other financial institutions as an intermediary. P2P attracts both borrower and lender where the borrower pays lesser interest and the lender can earn more interest since the borrower's overhead is reduced (Beaulieu et al., 2015). P2P gains its success stories for its capability to overcome early development problems. The ranking of $p 2 p$ has in fact jumped to second place after the rewards-based crowdfunding. Furthermore, the volume of $p 2 p$ for business lending in the UK for the last five years had reached $£ 1,490 \mathrm{~m}$ (Nesta, 2012).

\section{Equity-based Crowdfunding}

Apparently, the agenda of donation-based crowdfunding is to help others without any intention to obtain returns. The expansion of donation-based crowdfunding becomes the rewardsbased crowdfunding. The reward can be in the form of t-shirts, mugs, books, tickets, goodie bags, and as simple as printed name in flyers. When the company they funded (via donation or reward) begins to grow, increase revenues, and attract other investors, the former donors would wonder if they should receive some sort of appreciation for the success of the company. Unfortunately, donation and rewards-based crowdfunding do not allow such intention and the company has no obligation to fulfil the intention. Thus, equity crowdfunding (ECF) comes into picture. With equity crowdfunding, investors have a share in the company. A successful company will pay dividends to the investors and vice versa (Freedman \& Nutting, 2015).

However, equity-based crowdfunding is also the most complex crowdfunding model. It enables the investors to have ownership in the business, gain income when profitable, and share risks (Belleflamme et al., 2010). Equity crowdfunding enables young business ventures and commercial projects to get money from social virtue investors by transferring the company's ownership in the form of shares (Estrin et al., 2018; Hagedorn \& Pinkwart, 2016; Tuomi \& Harisson, 2017). The equity 
crowdfunding alternative financing emerges at the meeting point where public equity intersects with private equity that finances the business ventures, especially those at the start-up business level. However, since the shares of the individual investors are relatively small, they have no power to exercise the due diligence. In order to minimise the risk, the platform as an intermediary has to play its role to ensure the due diligence has been done prior to marketing the entrepreneur's campaign that could attract the investors' intention to invest (Audretsch et al., 2016).

Recently, Estrin et al. (2018) reported that equity crowdfunding in the UK has taken over traditional financing for early stage businesses. It provides the entrepreneur with the marketing place and enables them to be noticed. Interestingly, potential investors and customers could analyse the entrepreneur's project campaign online. Even though investors are new to this type of financing, they enter the market with proper investment knowledge. Thus, they are aware of the potential risks that are involved. In spite of this, equity crowdfunding is not always the entrepreneur's first choice in securing funding and there are circumstances where unprofitable companies with huge debts and highly intangible assets approach the ECF platform to improve their internal financing and debts volume. By doing this, the companies are transferring the risk to the crowd investors for their survival (Walthoff-Borm et al., 2017). Therefore, it is vital to undergo a thorough due diligence process and recognise the firms seeking funding via ECF. These processes will help disseminate clear information, reduce asymmetrical information, and prepare essential policy design that abet crowd investors to understand the risks involved. This is due to the fear that the crowdfunded company may fail after receiving the crowd's money (Ahlers et al., 2015). Protecting the crowd investor is the main reason for the high regulation of equity-based crowdfunding (Belleflamme et al., 2010).

\section{Firm's Human Capital}

The firm human capital for this study refers to founder and top management team. Many factors help in shaping an entrepreneurship. One of the factors is the entrepreneur or founder/director who plays an important role as the decision maker in executing the operation that reflects the firm's performance (Islam et al., 2011; Nimalathasan, 2008). The founder's demographic characteristic, for example, age, gender, alma mater, and previous experience tend to influence the firm's performance (Lucas, 2017; Sajilan et al., 2015). The entrepreneur's demography and organisational characteristic will significantly affect profitability. However, they are unable to explain the survival of the organisation (Auster, 1988). Even though this feature is not directly related to the success of the firm, it indeed exploits the skills, attitude, leadership, and managerial abilities that are most significant towards the better performance of the firm (Tanveer et al., 2013).

Top management team (TMT) plays an important role in the decision-making process of the firm. The first seminal study on TMT's relation to organisational outcome was initiated by Hambrick and Mason (1984) using the upper echelon approach. The study examined the effect of TMT's (i.e., chief executives) managerial characteristics (i.e., age, working duration in the organisation, the operational experience, educational background, lifestyle, and share ownership in the organisation) in the US. It concluded that TMT influenced organisational performance. In another study, Turturea, Jansen and Verheul (2015) examined TMT improvisation as a mediating factor on the firm's decision to bootstrap and bricolage. Again, TMT improvisation positively influenced firm performance. Nonetheless, bricolage helped improve while bootstrapping reduced the firm's performance respectively. 
Under the RBV theory, the top manager is considered as a firm's resource. Thus, the manager's decision is crucial as it will affect the firm's performance. To illustrate, the TMT's decision to outsource innovation activities will help reduce the risk of failure and high innovation costs. As a consequence, this promotes financial efficiency. TMT moderates the relationship between the RBV and transaction costs economics (TCE) as well as outsourcing decisions that result in performance (Wang \& Chen, 2016). In fact, different TMT's intelligent abilities provide several preferences for solving a problem or making a decision. In addition, while the TMT number in SMEs is relatively small, each of the TMTs' individual intelligence has larger weight than the TMT in big firms when deciding on highly risky projects (Rhodes et al., 2018).

The vertical dyad approach also shows the positive influence of TMT (i.e., chairperson) characteristics and enterprise performance. A study conducted on SMEs in China particularly discovered that the TMT's age and number of working years positively affected the enterprises' performance (Xu et al., 2019). Apart from carrying substance in SMEs, TMT further plays a significant role in promoting international expansion in corporate businesses as well (Sambharya, 1996). For some firms, international expansion reflects the market's competitiveness. For others, it is treated more towards economic obligation (Tihanyi et al., 2000). Based on the insights gathered from previous studies, it is clear that TMT positively influences firm performance. This study discusses social networks together with the founder-team relationship. This is due to crowdfunding spirit can be achieved via networks that are built internally and externally.

\section{Age}

Previous studies have provided different answers to the influence of the owner's age on firm performance. According to Welmilla, Weerakkody and Ediriweera (2011), age reflects people's lifetime and experiences. As they get older, their skills also improve. Many studies relate age and firm performance (Farrell et al., 2019; Zolin, 2015). The older founder tends to have more industry hours and investments in the financial assets of the firm which will directly influence the profit of the firm (Zolin, 2015). A firm which is directed by an older founder will generate higher incomes in the first year of operation in most of the sectors excluding hi-tech and manufacturing industries (Farrell et al., 2019). As people age, they acquire more knowledge, industry experience and reputations that lead to the new firm success (Dzathor et al., 2013). On the other hand, Tanveer et al. (2013) argue that age is still debatable. The older the person, the chances of becoming an entrepreneur is lesser. However, it significantly influences the firm's success. Earlier, Raposo, do Paço and Ferreira (2008) posit that entrepreneurial opportunities are more when the age increases. However, prior to the age of 24, not many individuals are lured to become entrepreneurs and when they get older, their enthusiasm to become an entrepreneur also declines. Age may not influence the success of the firm directly but as the person ages, he/she will gain more skills, experience, and capabilities that are significant in boosting firm success (Tanveer et al., 2013). It has been found that a new firm that is initiated by a senior business owner will survive albeit less vigorously (Farrell et al., 2019), as he/she will work in a smarter rather than harder way (Zolin, 2015).

\section{Gender}

Gender discloses that the female director's management characteristics are different from her male counterpart in terms of management style, the delegations of responsibility within the organisation, organisational structure, goals, and the degree of personal interest in the decision- 
INTERNATIONAL JOURNAL OF ACADEMIC RESEARCH IN BUSINESS AND SOCIAL SCIENCES

Vol. 10, No. 7, July, 2020, E-ISSN: 2222-6990 @ 2020 HRMARS

making that influence the overall performance (Mukhtar, 2002). However, the study on general human capital towards growth and survival depicts that female ventures has less potential to grow but will possibly survive (Cooper et al., 1994). This hypothesis is disagreed by Johnsen and McMahon (2005). Statistically, there is no relation between the male-female relationship towards performance and growth, finances and businesses of the organisation under the condition that the appropriate demographic factors and other relevant control factors have been considered in one research (Johnsen \& McMahon, 2005). The increase in participation of any gender will produce a curvilinear correlation between the gender composition and the performance of the organisation. Such composition induces similarity towards dissimilarity. Though the female percentage versus productivity relationship (i.e. total revenue per employee) shows irrelevant connection, there is a curvilinear correlation between the female percentage and profitability (i.e. net income before interest and taxes divided by total asset). This shows that the utilisation of the asset to generate income is different under gender diversity. Moreover, despite of the gender dominant effect on the organisation's performance, a more stable gender composition leads to higher organisational performance (Frink et al., 2003).

\section{Education Background}

Directors as the prime stakeholder need to address emerging issues strategically if they are to achieve good business performance (Jennings \& Beaver, 1997). The directors' industrial and management experiences (Isaga, 2015; Kelliher \& Reinl, 2009), family business nature, entrepreneurial seminar, and hands-on training positively relate to the performance of the organisation. In fact, the educational background and the entrepreneurial experience of the founders/directors are incompatibles in determining the firm's performance (Isaga, 2015). However, according to Do Paço, Ferreira, Raposo, Rodrigues and Dinis (2015), entrepreneurial education is not necessarily the main factor in becoming an entrepreneur. Their study empirically investigated two sets of respondents from different schools. One set consisted 729 female students from an all-female school and the students were exposed to entrepreneurship. Another set was composed of 286 male students from a school that specialised in sports. The findings show that male students were more into entrepreneurship rather than female students. Therefore, it can be said that the formal education of the founder does not determine the success factor, as informal education can also become the success factor (Keith et al., 2016). Moreover, the educational background of the founder does not influence the innovation strategy employed by the firm (Kato et al., 2015).

\section{Experience}

In the case of new start-up firms, the prior experience of the founder will likely influence the firm achievement (Delmar \& Shane, 2006). Founders with managerial experience have more opportunity to exploit. They believe that risk means opportunity. High risk means high returns. Thus, founders with managerial experience would rather exploit different opportunities (Dencker \& Gruber, 2015; Gruber, 2010). A founder with managerial experience also tends to embrace prior experience into his/her new start-up firm and he/she is free to exploit the opportunity.

A founder with industrial experience, on the other hand, is more restricted. He/she will likely restrict him/herself from entering risky opportunities. Dencker and Gruber (2015) empirically show that the different experiences gained by the founders will trigger different knowledge that will importantly influence the firm's performance. Their knowledge and skill will not only influence the 
INTERNATIONAL JOURNAL OF ACADEMIC RESEARCH IN BUSINESS AND SOCIAL SCIENCES

Vol. 10, No. 7, July, 2020, E-ISSN: 2222-6990 @ 2020 HRMARS

performance directly but also indirectly. According to Protogerou, Caloghirou and Vonortas (2017), both will positively impact the innovative activities in the new firm.

\section{Social Networks}

Social capital network indicates the substantial connection between the sizes of the social media network in relation to the success of the funding campaign (Mollick, 2014). Mollick (2014) distinguishes social networks into two types; the internal and external social networks. The former refers to social networks with the crowdfunding platform, whereas the latter refers to the creators' own developed social networks afar from the platforms. Fatoki (2011) emphasises that social capital can be improved if a robust network connection with the stakeholders is preserved. To ensure it works, the directors have to play their roles to improve their ties by participating in exhibitions, seminars, trade associations, and trade fairs. On top of that, Fatoki and Oni (2014) contend that the domination of network connections (i.e., social, official, and business) lies on which phase of business the firm is in. At the start-up level, the social networks dominate official and business networks. On the other hand, business network dominates social network ties during the establishment phase of business, even though at this stage social network still plays a role in providing resources by family members and acquaintances who are also the employees of the firm.

The social networks can be seen from two facets; structural and cognitive dimensions. The structural dimension is represented by the entrepreneur's social media connections, for example, Facebook and Instagram. The cognitive dimension, on the other hand, is discovered from the amount of words used by the creator during the crowdfunding campaign as displayed on the platform. Both of them are capable to influence the crowdfunding performance. The higher the number of social media friendsters and words used during the campaign, the higher is the crowdfunding success rate and vice versa (Aprilia \& Wibowo, 2016). In addition, the interconnection between social capital and human skills provides a clearer understanding on the construction of one's social capital towards the decision on technology application. In this study, the interaction between social capital networks and the crowdfunding ecosystem takes into account the different components of social capital, including innovative behaviour, empathy, and teamwork between the entrepreneurship and crowdfunding platform (see Hunecke et al., 2017). Meanwhile, Lin and Pursiainen (2018) argue that the social network plays a crucial in reducing moral hazard in crowdfunding-related businesses. Even though social network has the tendency to create trustworthy conduct, they argue that in reality, highly social network communities are unable to deter the entrepreneur from committing fraud.

In most literatures available, networking-related competency is always referred to as the founder's ability to network personally (Jones et al., 2011). Most of the studies empirically show that SMEs with international networking will perform better. The idea behind it is that the international market saturates smaller than the domestic SMEs. However, the networking-related capabilities of SMEs under the crowdfunding umbrella are in need of further exploration, as the issue is concerned with possibility of the funding to go international due to internet application rather than product, services, or establishment. Under the crowdfunding umbrella, social capital network indicates a substantial connection between the sizes of the social media network in relation to the success of the funding campaign (Mollick, 2014). Where substantial number of social networks could influence investors to pump in more money when needed (Roma et al., 2017). 
INTERNATIONAL JOURNAL OF ACADEMIC RESEARCH IN BUSINESS AND SOCIAL SCIENCES Vol. 10, No. 7, July, 2020, E-ISSN: 2222-6990 @ 2020 HRMARS

\section{External Networks}

Previous studies on social capital in the crowdfunding sphere emphasise on how external social capital in the form of third-party social network contacts (Giudici et al., 2013; Mollick, 2014; Zheng et al., 2014), and family-friends (Kuppuswamy \& Bayus, 2018; Ordanini et al., 2011) affect funding outcomes. Empirically, it has been shown that early-stage backing from these private networks generate a reinforcement tool that leads to immediate funding success (Kuppuswamy \& Bayus 208; Lehner, 2013; Ordanini et al., 2011). In spite of that, family-friends ties relate to first-time sponsoring (Agrawal et al., 2015; Bygrave, 2004; Bygrave et al., 2003).

A study conducted by Liao et al. (2015) did not conclude significantly the relationship of both types of social capital to the success of crowdfunding which would later affect the survival of the firm. However, for investment-based crowdfunding projects, the existence of internal and external social networks plays an important role that significantly influences performance. Hence, this shows that when founders support other founders' crowdfunding project, this will help their own project when it is launched on the platform in the future.

\section{Platform Provider}

In the United States, more than USD five billion were raised through crowdfunding platform providers in 2013 alone. It then increased to 188 per cent for the next year (Montini, 2014). The platforms establish chances for start-ups and SMEs in particular to obtain money by bridging the entrepreneurs and investors. At the same time, they maintain the secrecy that tie them up (Mollick, 2014; Ordanini et al., 2011). As crowdfunding forms are different, the platforms' role also differs from each other. They shift from non-pecuniary to pecuniary motives (Calic \& Mosakowski, 2016).

Platform providers potentially attract the investor's willingness to participate on the project launched on the platform rather than word of mouth attraction (Lacan \& Desmet, 2017). In equity crowdfunding, government intervention towards the crowdfunding platform increases the herding effect of the investors. This is due to better information disclosure and standard of operation to be adhered by the platform. As the consequence, the herding effect reduces the investor's risk exposure, hence, increases the investor's level of confidence (Jiang et al., 2018). Further exploration determines the existence of herding effect under pecuniary-based crowdfunding platforms. Platform with a high number of investors subsequently attracts other potential investors (Jiang et al., 2018).

Table 1 below represents four ECF platforms in Malaysia. These are platforms that provide information as mentioned in the tables. Other ECF platforms that are unable to provide the information needed are excluded. According to Kassim, Wahab and Muhamed (2020), ECF platforms in Malaysia play important roles in assist the entrepreneurs that interested in ECF. The table shows that Pitchin platform has been approached by many entrepreneurs and the investors. All entrepreneurs that successfully placed their campaigns on the Pitchin's platform managed to fulfil their funding goals.

\section{Internal Networks}

The internal social capital network in crowdfunding is described as a relationship which exists in the crowdfunding ecosystem between the founder and the platform provider (Liao et al., 2015). They would mutually share the group's determination and goals under the similar guidelines, which relates to the mutual acts of the members that would possibly generate opportunities among them (Huber, 2009). In all actuality, building a trustworthy relationship within the crowdfunding population 
INTERNATIONAL JOURNAL OF ACADEMIC RESEARCH IN BUSINESS AND SOCIAL SCIENCES Vol. 10, No. 7, July, 2020, E-ISSN: 2222-6990 @ 2020 HRMARS

for funding success is essential (Helmer, 2014). According to Zheng, Li, Wu and Xu (2014), the relationship can be identified from the website where the campaign is launched. In the case where another founder 'likes' and 'supports' another member's project, this will attract potential investors to invest and also indicates the obligation of another party to back the future project of others in the group as it displays closeness and trustworthiness.

Both closeness and trustworthiness spur the performance and social capital (Moran, 2005). As a result, the trusted projects will attract the potential investors and increase the possibility to be funded (Liao et al., 2015), thus increasing firm performance. In addition, Skirnevskiy et al., (2017) provided evidence that the internal social network is capable of promoting creator-backers relationship that provides future competitive advantage. This enables the creation of loyal backers' community to support the creator's future campaign. This loyal crowdfunding community acts as the resources to the venture. The study also determined the possibility of internal networking superseding the external networking "family and friends" ties for future campaign success. The present study will attempt to measure the potential of social capital networks to the growth and productivity of the SMEs.

As shown in table 1, Pitchin has many followers as compared to other platforms. Thus, this might one of the reason more investors interested in this platforms.

Table 1: ECF Platforms in Malaysia

\begin{tabular}{|c|l|c|c|c|c|}
\hline & & \multicolumn{3}{|c|}{ ECF Platforms (2017 - 2019) } \\
\hline 1 & $\begin{array}{l}\text { Issuers/success } \\
\text { campaign }\end{array}$ & 40 & 15 & 10 & 5 \\
\hline 2 & $\begin{array}{l}\text { Total Investment raised } \\
\text { (MYR) }\end{array}$ & $>40$ million & $>9$ million & $>9$ million & $>4$ million \\
\hline 3 & $\begin{array}{l}\text { Total Investors } \\
\text { Participated }\end{array}$ & 2268 & $\begin{array}{c}\text { Not } \\
\text { Available }\end{array}$ & 684 & 155 \\
\hline 4 & Info. On Shares Offered & Available & $\begin{array}{c}\text { Not } \\
\text { Available }\end{array}$ & $\begin{array}{c}\text { Not } \\
\text { Availbale }\end{array}$ & Available \\
\hline 5 & FB Followers & 11432 & $\begin{array}{c}\text { Not } \\
\text { Available }\end{array}$ & 4100 & 1607 \\
\hline 6 & Exit History & 1 & 0 & 1 & 0 \\
\hline
\end{tabular}

Source (Kassim et al., 2020)

\section{Research and Methodology}

This study adopts conceptual research approach by examining and analysing previous literatures on the topic. This study will answer the following questions; i) how founder, TMT, and networks influence the performance of the ECF funded firm and ii) how platform moderates the FTMT and networks to influence the performance of the firm.

\section{Theoretical Framework}

This study could be best explained by the underpinning theory of small firm performance together with the bricolage theory in finance and the signalling theory. 
INTERNATIONAL JOURNAL OF ACADEMIC RESEARCH IN BUSINESS AND SOCIAL SCIENCES Vol. 10, No. 7, July, 2020, E-ISSN: 2222-6990 @ 2020 HRMARS

\section{Theory of Small Firm Performance}

In measuring small firm's performance, most of the studies in the literature would adopt the theoretical framework established by Storey (1994). The theory highlights the demographic features of the firm, the founder-director's characteristics, and the strategy/ies employed are the important factors that influence the firm performance. Among the notable studies include those conducted by Halabi et al. (2010), Ebben \& Johnson (2011), Chen \& Yu (2012), and Blackburn, et al., (2013). The founder and TMT as a proxies for the firm play an important roles that lead to wise decision making. For instance, when the TMT decide on using ECF to fund their project as explained in the next theory.

\section{Theory of Financial Bricolage}

However, Desa and Basu (2013) argue that further research should be done to examine the bricolage effect on performance, and specifically, innovation. As the concept of the theory of bricolage is to take advantage of entrepreneurial opportunities, it can thus be internal and external. Internal bricolage refers to the entrepreneur's characteristics; experience and knowledge of the market, customers' issues and other attributes that will help to encounter issues and capture emerging opportunities. External bricolage, on the contrary, indicates the entrepreneur's behaviour to fully utilise the external resources available at that time (Vanevenhoven et al., 2011).

Nevertheless, both serve the purposes of generating new combinations of resourceful inputs with the intention to foster firm performance (Brush et al., 2001; Kariv \& Coleman, 2015; Sirmon \& Hitt, 2003). A previous study by Kariv and Coleman (2015) adopts RBV with the extension of the theory of bricolage from the perspective of microloan. The present study will investigate the matter from the perspective of equity crowdfunding. This theory helps to explain the founder-director's or top management team's behaviour or ability to take up opportunities from the equity crowdfunding event for the benefit of the firm. On top of that, any decision or actions taken will signal other parties that might interested in the firm's project.

\section{Theory of Signalling}

The signalling theory which was introduced by Spence (1973) can be applied to various fields; economic, accounting, finance, entrepreneurship, and education. It is a theory that helps to elaborate the behaviour of organisations or individuals when dealing with asymmetric information. It is vital for the receiver to be able to interpret the signal sent by the sender, hence lessening the asymmetric information between the involved parties (Spence, 2002). Connelly, Certo, Ireland and Reutzel (2011) argue about the dynamic of the signalling theory.

Equity crowdfunding, for instance, observe that investors as the receiver would show an interest on start-up that signals "signal fit" and "low degree of ambiguity." Substantially, these two signals of human capital of the sender (entrepreneur) influence the success of the campaign by convincing the investors' motivation to participate (Piva \& Rossi-Lamastra, 2018). However, from the perspective of prior financing, firms that have financing history with sophisticated or retail investors, BAs, project grants and venture capitalists portray quality relationships. This relationship will positively influence the equity crowdfunding campaign success. When a firm's social capital and human capital are at par, this tends to make its crowdfunding campaign successful (Kleinert et al., 2018; Signori \& Vismara, 2016). 
INTERNATIONAL JOURNAL OF ACADEMIC RESEARCH IN BUSINESS AND SOCIAL SCIENCES Vol. 10, No. 7, July, 2020, E-ISSN: 2222-6990 @ 2020 HRMARS

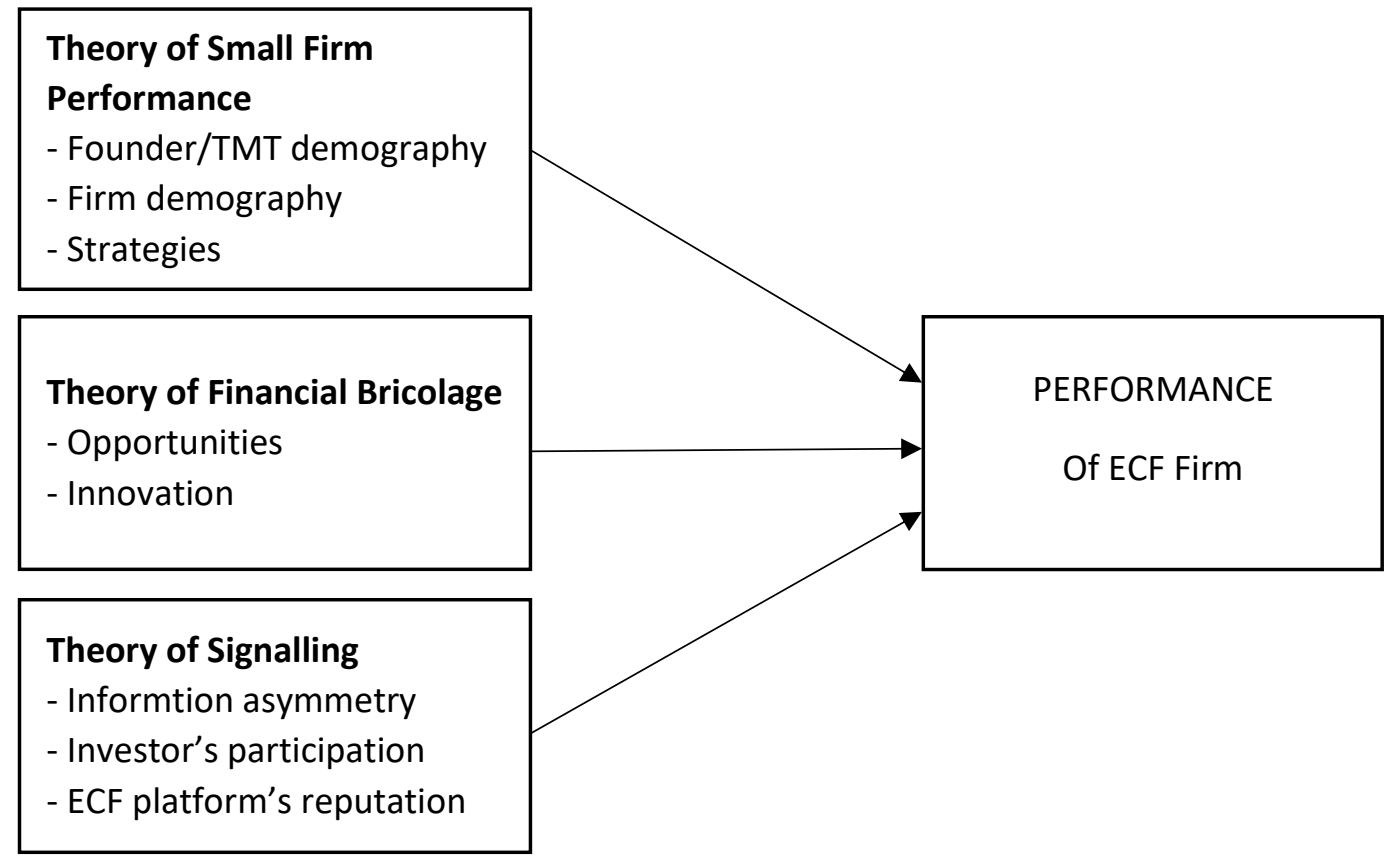

Source: Author's Illustration

Figure 1: Theoretical Framework

The figure 1 summarizes the linkage of these three theories towards the performance of the ECF firms. It illustrates the knowledgeable entrepreneur would know when to grab the opportunities and how to get the resources needed as explained by financial theory of bricolage. Knowingly, startup and new firms are exposed to many risks, thus, the entrepreneur responsible to reduce the asymmetry information that might tarnish the firm. This when the signalling theory can be applied in the ECF ecosystem. The signal provides the ECF stakeholders information on the firm performance.

\section{Findings}

Funding from ECF is up to MYR 3 million and can be increased by another MYR 2 million in the following year (Securities Commission of Malaysia, 2017). Thus, shows that ECF funding is not the ultimate funding for the entrepreneurial ventures (Caldbeck, 2013). However, it can can be a jumpstart especially for start-up to operate and get acknowledgment from the public about their products or services (Caldbeck, 2014). The findings indicate that founder and TMT are part of the firm vital assets. The quality human asset in one firm implicitly signal its value. Under ECF ecosystem, other than founder and TMT, the social networks play a vital roles too.

Before the ECF, the networks merely related to families and friends. After the crowdfunding process, the networks getting bigger and bigger. This is the effect of 'the wisdom of crowd' (Clauss et al., 2018). The strong networks explain the trustworthiness and closeness remain in the firm. Once the entrepreneur decides for ECF fund, first thing first he or she has to make contact with PP. This PP has its own networks. As an entrepreneur, being recognized by PP networks is an added advantage. The reason is that PP networks comprise of business angels and venture capitalist which have more capital for investment. The effect of crowdfunding does not stop when the campaign end. Thus, ECF funded firm with its promising human capital, social capital and reputable platform provider able to convert the business plan attractiveness that able to attract financial capital from investors when needed. ECF platform and government intervention help evolve entrepreneurship in Malaysia. 
INTERNATIONAL JOURNAL OF ACADEMIC RESEARCH IN BUSINESS AND SOCIAL SCIENCES

Vol. 10, No. 7, July, 2020, E-ISSN: 2222-6990 @ 2020 HRMARS

Knowledge is important. Especially knowledge that relates to current mainstream involving entrepreneurship and entrepreneurial financing. As an entrepreneur it is vital to equip himself to the standard of this mainstream.

\section{Discussion}

There are various factors could influence the performance of the firms. In this study, founder, TMT and their networks are considered as internal factors and the platform provider is the external factor that affected the performance. In addition, Marinova, Plantenga and Remery (2016) suggest further investigation on gender diversity and firm performance. Whereas, Lucas (2017) highlights that family-based firms are less likely perform better than cooperatives, partnerships, private companies, public companies. He also added that male-generated firms' performance are higher than femaleoperated firms.

However, in this study, the ECF highlights that the quality of founder and his team, the large number of social networks they have and the highflying platform they engaged with are part of the reason the investors making their decision to invest. As a consequences, the performance of the ECF funded firms improve. Again this study is a conceptual based, the empirical finding is needed to support the findings.

The ECF platform is one of the main actors in the process. It acts as the "network orchestra" that connect the entrepreneurs and investors. Thus, prior to participate in the ECF, the entrepreneur is encouraged to build "personal contact" with the platform. The entrepreneur needs to be noticeable by the platform's network. After all, the selection criteria of the platform is almost the same with business angel and venture capitalist (Löher, 2017). Ahead of fulfil the entrepreneurs funding need, the ECF platforms provides more benefits in term of social networks. According to Brown, Mawson and Rowe (2019), these social networks change along the crowdfunding process. Where they will evolve to business network that is essential for the start-up to grow.

\section{Conclusion}

The emergence of ECF fund and its comrades have evolved the entrepreneurial landscape of developing and developed countries worldwide. More than that crowdfunding can be tailored according to the fund needed based on the project purposes. It has been widely used in real estate (Cohen, 2016), agricultural (Anshari et al., 2019) and health industries in many countries (Al-Kadi \& Chatterjee, 2012). The revolution in financial industry known as fintech, even though it disrupts the traditional banking system, it makes the crowdfunding process more viable. In fact, some of the banks have collaborated and tailor their business model featuring the new emergent fund, ECF. For example in Malaysia the establishment of Investment Account Platform (IAP) (Kasri \& Muhammad, 2019). This platform is where the entrepreneurs will approach for funding. Then they will be channelled to the 'funders' via the anticipated Islamic banks (Investment Account Platform, 2016). The uniqueness of this research is that previous studies yet to discuss how PP moderates the effect of founder, TMT and networks towards the ECF funded firm performance. The importance of PP in assists the firms to obtain more funding for growth.

Platforms with vast networks influence investors' participation. Hence, influence the success of the ECF campaigns. These networks also shape the post-event performance of the firm (Brown et al., 2019). It provides an alternative resources that is crucial for the survival of the firm. Even though, ECF is not the ultimate funding for the entrepreneurs, it evolves the entrepreneurial landscape that 
no longer depends solely on financial institution. The unique of this type of funds is that it can be tailored according to the entrepreneur's funding need (Mayorova \& Petrenko, 2018). Hence, as an entrepreneur the knowledge and skills are essential tools in exploring ECF and other fintech tools such as blockchain (Roth et al., 2019) that would unlocked opportunities beyond their expectation. Knowledge about which platform gives better offer, services and assistance to secure ECF fund effectively (Loher, 2017) and designs growth program for them. This is in line with the entrepreneurship knowledge spillover theory. Where according to this theory, high knowledge settings generate more entrepreneurial opportunities (Audretsch \& Keilbach, 2007).

The government and its agencies need to magnify their strategy to assist the platforms to increase their potential effectively (Troise, 2019); assist the entrepreneur to gain the accurate and adequate knowledge related to the new emergence fintech tools, specifically the ECF that is in line with the financial theory of bricolage (Kariv \& Coleman, 2015). Meanwhile, the higher learning institutions need to adapt ECF and its associates into their entrepreneurship learning cohort. The crowdfunding and other financial technology affect the current entrepreneurial landscape and they will continuously change it in the future.

Exposure to crowdfunding should covers the wide spectrum of crowdfunding such as ECF, P2P and real estate crowdfunding (Mayorova \& Petrenko, 2018) and should not be restricted to donationbased only (Man et al., 2019). There are many rooms of ECF can be explored and investigated by researchers. For instance, the impact of ECF fund on the performance of the crowdfundee firms in Malaysia. Thus, this study contributes to the theoretical in term of the application of the chosen theories in the crowdfunding studies particularly in Malaysia.

\section{Corresponding Author}

Siti Fatimah Mohd Kassim ${ }^{1}$ (PhD Candidate-Main Author)

Email address: anafatimah315@gmail.com 
INTERNATIONAL JOURNAL OF ACADEMIC RESEARCH IN BUSINESS AND SOCIAL SCIENCES

Vol. 10, No. 7, July, 2020, E-ISSN: 2222-6990 @ 2020 HRMARS

\section{References}

Agrawal, A., Catalini, C., \& Goldfarb, A. (2015). Crowdfunding: Geography, Social Networks, and The Timing of Investment Decisions. Journal of Economics and Management Strategy, 24(2), 253274.

Ahlers, G. K., Cumming, D., Günther, C., \& Schweizer, D. (2015). Signalling In Equity Crowdfunding. Entrepreneurship Theory and Practice, 39(4), 955-980.

Al-Kadi, A., \& Chatterjee, S. (2012). Tapping the Wisdom of Crowd Phenomenon in Healthcare Social Networks. International Journal of Business Data Communications and Networking (IJBDCN), 8(3), 42-56.

Anshari, M., Almunawar, M. N., Masri, M., \& Hamdan, M. (2019). Digital Marketplace and Fintech To Support Agriculture Sustainability. Energy Procedia, 156, 234-238.

Aprilia, L., \& Wibowo, S. S. (2016). The Impact of Social Capital on Crowdfunding Performance: A Case Study of Kitabisa.Com. Proceedings of International Conference on Contemporary Economic Issues, 96.

Audretsch, D. B., Lehmann, E. E., Paleari, S., \& Vismara, S. (2016). Entrepreneurial Finance and Technology Transfer. The Journal of Technology Transfer, 41(1), 1-9.

Audretsch, D. B., \& Keilbach, M. (2007). The Theory of Knowledge Spillover Entrepreneurship. Journal of Management Studies, 44(7), 1242-1254.

Auster, E. R. (1988). Owner and Organisational Characteristics of Black- And White-Owned Businesses: Self-Employed Blacks Had Less Training, Fewer Resources, Less Profits, But Had Similar Survival Rates. American Journal of Economics and Sociology, 47(3), 331-344.

Beaulieu, T., Sarker, S., \& Sarker, S. (2015). A Conceptual Framework for Understanding Crowdfunding. Communications of The Association for Information, 37, 1-31.

Belleflamme, P., Lambert, T., \& Schwienbacher, A. (2010). Crowdfunding: An Industrial Organisation Perspective. 1-30. Retrieved from Https://Pdfs.Semanticscholar.Org/2d6e/0c9bfc762e88656ff63a3a109e237f0bf8a0.Pdf.

Brown, R., Mawson, S., \& Rowe, A. (2019). Start-Ups, Entrepreneurial Networks and Equity Crowdfunding: A Processual Perspective. Industrial Marketing Management, 80, 115-125.

Brush, C. G., Greene, P. G., \& Hart, M. M. (2001). From Initial Idea to Unique Advantage: The Entrepreneurial Challenge of Constructing A Resource Base. Academy of Management Perspectives, 15(1), 64-78.

Bygrave, W. D. (2004). Founders, Family, Friends, And Fools. Retrieved from Https://Www.Bloomberg.Com/News/Articles/2004-09-02/Founders-Family-Friends-AndFools

Bygrave, W., Hay, M., Ng, E., \& Reynolds, P. (2003). Executive Forum: A Study of Informal Investing In 29 Nations Composing the Global Entrepreneurship Monitor. Venture Capital: An International Journal of Entrepreneurial Finance, 5(2), 101-116.

Che Man, N., Rameli, P., Faizal, M., Wahab, A., Azlina, N., Jaapar, N., \& Rabu, N. (2019). Crowdfunding practices in higher education institutions in Malaysia: the case of Universiti Teknologi MARA Cawangan Melaka (UiTMCM). Journal of Islamic Philanthropy \& Social Finance, 2(1), 1-18.

Cohen, J. (2016). "A Study on the History and Functionality of Real Estate Crowdfunding," Joseph Wharton Scholars. Available at Http://repository.upenn.edu/joseph_wharton_scholars/19

Caldbeck, R., (2013). Crowdfunding - Why Angels, Venture Capitalists and Private Equity Investments All May Benefit. Forbes (August 7. Available at http://www.forbes.com/ 
INTERNATIONAL JOURNAL OF ACADEMIC RESEARCH IN BUSINESS AND SOCIAL SCIENCES

Vol. 10, No. 7, July, 2020, E-ISSN: 2222-6990 @ 2020 HRMARS

sites/ryancaldbeck/2013/08/07/crowdfunding-why-angels-venture-capitalists-andprivateequity-investors-all-may-benefit/, last Accessed 11 February 2016).

Caldbeck, R. (2014). Using Crowdfunding to Validate (Or Invalidate) Ideas. Wall Street Journal, (November 17).

Calic, G., \& Mosakowski, E. (2016). Kicking Off Social Entrepreneurship: How A Sustainability Orientation Influences Crowdfunding Success. Journal of Management Studies, 53(5), 738767.

Clauss, T., Breitenecker, R. J., Kraus, S., Brem, A., \& Richter, C. (2018). Directing the Wisdom of the Crowd: The Importance of Social Interaction Among Founders and The Crowd During Crowdfunding Campaigns. Economics of Innovation and New Technology, 27(8), 709-729.

Connelly, B. L., Certo, S. T., Ireland, R. D., \& Reutzel, C. R. (2011). Signalling Theory: A Review and Assessment. Journal of Management, 37(1), 39-67.

Cooper, A. C., Gimeno-Gascon, F. J., \& Woo, C. Y. (1994). Initial Human and Financial Capital as Predictors of New Venture Performance. Journal of Business Venturing, 9(5), 371-395.

Delmar, F., \& Shane, S. (2006). Does Experience Matter? The Effect of Founding Team Experience on The Survival and Sales of Newly Founded Ventures. Strategic Organisation, 4(3), 215-247.

Dencker, J. C., \& Gruber, M. (2015). The Effects of Opportunities and Founder Experience on New Firm Performance. Strategic Management Journal, 36(7), 1035-1052.

Desa, G., \& Basu, S. (2013). Optimisation or Bricolage? Overcoming Resource Constraints in Global Social Entrepreneurship. Strategic Entrepreneurship Journal, 7(1), 26-49.

Do Paço, A., Ferreira, J. M., Raposo, M., Rodrigues, R. G., \& Dinis, A. (2015). Entrepreneurial Intentions: Is Education Enough? International Entrepreneurship and Management Journal, 11(1), 57-75.

Dzathor, A. Y., Mosley, A. L., \& White, M. M. (2013). A Longitudinal Examination of The Impact of Founding Owner Operator Characteristics on Nascent Venture Performance: Evidence from The Kauffman Firm Survey. International Journal of Business and Social Research, 3(5), 50-61.

Estellés-Arolas, E., \& González-Ladrón-De-Guevara, F. (2012). Towards an Integrated Crowdsourcing Definition. Journal of Information Science, 38(2), 189-200.

Estrin, S., Gozman, D., \& Khavul, S. (2018). The Evolution and Adoption of Equity Crowdfunding: Entrepreneur and Investor Entry into A New Market. Small Business Economics, 51(2), 425439.

Farrell, D., Wheat, C., \& Mac, C. (2019). Gender, Age, And Small Business Financial Outcomes, 1-24. Retrieved From

Https://Www.Jpmorganchase.Com/Corporate/Institute/Document/Institute-Report-SmallBusiness-Financial-Outcomes.Pdf

Fatoki, O. O. (2011). The Impact of Human, Social and Financial Capital on the Performance of Small and Medium-Sized Enterprises (Msmes) in South Africa. Journal of Social Sciences, 29(3), 193204.

Fatoki, O., \& Oni, O. (2014). The Networking Behaviour of Immigrant Entrepreneurs in South Africa. Mediterranean Journal of Social Sciences, 5(20), 284-290.

Freedman, D. M., \& Nutting, M. R. (2015). Equity Crowdfunding for Investors: A Guide To Risks, Returns, Regulations, Funding Portals, Due Diligence, And Deal Terms. Hoboken, New Jersey: John Wiley \& Sons, Inc. 
INTERNATIONAL JOURNAL OF ACADEMIC RESEARCH IN BUSINESS AND SOCIAL SCIENCES Vol. 10, No. 7, July, 2020, E-ISSN: 2222-6990 @ 2020 HRMARS

Frink, D. D., Robinson, R. K., Reithel, B., Arthur, M. M., Ammeter, A. P., Ferris, G. R., \& Morrisette, H. S. (2003). Gender Demography and Organisation Performance: A Two-Study Investigation with Convergence. Group and Organisation Management, 28(1), 127-147.

Frydrych, D., Bock, A. J., Kinder, T., \& Koeck, B. (2014). Exploring Entrepreneurial Legitimacy in Reward-Based Crowdfunding. Venture Capital, 16(3), 247-269.

Giudici, G., Guerini, M., \& Lamastra, C. R. (2013). Why Crowdfunding Projects Can Succeed: The Role of Proponents' Individual and Territorial Social Capital (April 24, 2013). Available at SSRN: https://ssrn.com/abstract=2255944 or http://dx.doi.org/10.2139/ssrn.2255944.

Gruber, M. (2010). Exploring the Origins of Organisational Paths: Empirical Evidence from Newly Founded Firms. Journal of Management, 36(5), 1143-1167.

Hagedorn, A., \& Pinkwart, A. (2016). The Financing Process of Equity-Based Crowdfunding: An Empirical Analysis. In D. Brüntje, \& O. Gajda (Eds.), Crowdfunding in Europe: State of The Art in Theory and Practice (Pp. 71-85). Springer International Publishing.

Hambrick, D. C., \& Mason, P. A. (1984). Upper Echelons: The Organisation as A Reflection of Its Top Managers. The Academy of Management Review, 9(2), 193-206.

Hemer, J. (2011). A Snapshot on Crowdfunding. Retrieved from Https://Www.Econstor.Eu/Bitstream/10419/52302/1/671522264.Pdf

Huber, F. (2009). Social Capital of Economic Clusters: Towards A Network-Based Conception of Social Resources. Tijdschrift Voor Economische En Sociale Geografie, 100(2), 160-170.

Hunecke, C., Engler, A., Jara-Rojas, R., \& Poortvliet, P. M. (2017). Understanding the Role of Social Capital in Adoption Decisions: An Application to Irrigation Technology. Agricultural Systems, 153, 221-231.

Investment Account Platform, (2016). (online). Investment Account Platform. Available from: www.iaplatform.com. (Accessed 22 February 2016).

Isaga, N. (2015). Owner-Managers' Demographic Characteristics and The Growth of Tanzanian Small and Medium Enterprises. International Journal of Business and Management, 10(5), 168-181.

Islam, M. A., Khan, M. A., Obaidullah, A. Z. M., \& Alam, M. S. (2011). Effect of Entrepreneur and Firm Characteristics on The Business Success of Small and Medium Enterprises (Smes) In Bangladesh. International Journal of Business and Management, 6(3), 289-299.

Jennings, P., \& Beaver, G. (1997). The Performance and Competitive Advantage of Small Firms: A Management Perspective. International Small Business Journal, 15(2), 63-75.

Jiang, Y., Ho, Y. C., Yan, X., \& Tan, Y. (2018). Investor Platform Choice: Herding, Platform Attributes, And Regulations. Journal of Management Information Systems, 35(1), 86-116.

Johnsen, G. J., \& Mcmahon, R. G. (2005). Owner-Manager Gender, Financial Performance and Business Growth Amongst Smes From Australia's Business Longitudinal Survey. International Small Business Journal, 23(2), 115-142.

Jones, M. V., Coviello, N., \& Tang, Y. K. (2011). International Entrepreneurship Research (1989-2009): A Domain Ontology and Thematic Analysis. Journal of Business Venturing, 26(6), 632-659.

Kariv, D., \& Coleman, S. (2015). Toward A Theory of Financial Bricolage: The Impact of Small Loans on New Businesses. Journal of Small Business and Enterprise Development, 22(2), 196-224.

Kasri, N. S., \& Muhammad, M. (2019). "The Investment Account Platform: A Practical Application of Fintech In Malaysia". In Fintech In Islamic Finance (Pp. 249-264). Routledge.

Kassim, S.F., Wahab, K., \& Muhamed, N. A. (2020). Equity Crowdfunding as an Alternative Financing For Entrepreneurs In Malaysia: An Analysis On The Features And Offerings Of Platform 
INTERNATIONAL JOURNAL OF ACADEMIC RESEARCH IN BUSINESS AND SOCIAL SCIENCES

Vol. 10, No. 7, July, 2020, E-ISSN: 2222-6990 @ 2020 HRMARS

Providers. Proceedings of the 2nd International Conference on Economics, Entrepreneurship and Management 2020 (ICEEM2020). ICEEM2020: 028-022.

Kato, M., Okamuro, H., \& Honjo, Y. (2015). Does Founders' Human Capital Matter for Innovation? Evidence from Japanese Start-Ups. Journal of Small Business Management, 53(1), 114-128.

Keith, N., Unger, J. M., Rauch, A., \& Frese, M. (2016). Informal Learning and Entrepreneurial Success: A Longitudinal Study of Deliberate Practice Among Small Business Owners. Applied Psychology, 65(3), 515-540.

Kelliher, F., \& Reinl, L. (2009). A Resource-Based View of Micro-Firm Management Practice. Journal of Small Business and Enterprise Development, 16(3), 521-532.

Kleinert, S., Volkmann, C., \& Grünhagen, M. (2018). Third-Party Signals in Equity Crowdfunding: The Role of Prior Financing. Small Business Economics, 1-25.

Kraus, S., Richter, C., Brem, A., Cheng, C. F., \& Chang, M. L. (2016). Strategies for Reward-Based Crowdfunding Campaigns. Journal of Innovation and Knowledge, 1(1), 13-23.

Kuppuswamy, V., \& Bayus, B. L. (2018). Crowdfunding Creative Ideas: The Dynamics of Project Backers. In D. Cumming, \& L. Hornuf (Eds.), The Economics of Crowdfunding: Startups, Portals, And Investor Behaviour (Pp. 151-182). Palgrave Macmillan.

Lacan, C., \& Desmet, P. (2017). Does the Crowdfunding Platform Matter? Risks of Negative Attitudes in Two-Sided Markets. Journal of Consumer Marketing, 34(6), 472-479.

Lehner, O. M. (2013). Crowdfunding Social Ventures: A Model and Research Agenda. Venture Capital, 15(4), 289-311.

Liao, C., Zhu, Y., \& Liao, X. (2015). The Role of Internal and External Social Capital in Crowdfunding: Evidence from China. Revista De Cercetare Si Interventie Socialâ, 49, 187-204.

Lin, T. C., \& Pursiainen, V. (2018). Fund What You Trust? Social Capital and Moral Hazard in Crowdfunding. Social Capital and Moral Hazard in Crowdfunding. Retrieved from Https://Pdfs.Semanticscholar.Org/95dc/F51cca753bf294d052605fb39925f8f573dd.Pdf.

Löher, J. (2017). The Interaction of Equity Crowdfunding Platforms and Ventures: An Analysis of The Preselection Process. Venture Capital, 19(1-2), 51-74.

Lucas, S. (2017). The Impact of Demographic and Social Factors on Firm Performance in Kenya. Journal of Business and Economic Development, 2(4), 255-261.

Marinova, J., Plantenga, J., \& Remery, C. (2016). Gender Diversity and Firm Performance: Evidence from Dutch And Danish Boardrooms. The International Journal of Human Resource Management, 27(15), 1777-1790.

Mollick, E. R. (2014). The Dynamics of Crowdfunding: An Exploratory Study. Journal of Business Venturing, 29(1), 1-16.

Montini, L. (2014). Crowdfunding's Popularity Surged In 2013. Retrieved from Https://Www.Inc.Com/Laura-Montini/The-Rapid-Rise-Of-Crowdfunding.Html

Moran, P. (2005). Structural Vs. Relational Embeddedness: Social Capital and Managerial Performance. Strategic Management Journal, 26(12), 1129-1151.

Mayorova, T., \& Petrenko, I. (2018). Crowdfunding as An Innovative Platform for Smes Development. Wydawnictwo Państwowej Wyższej Szkoły Zawodowej Im. Prof. Stanisława Tarnowskiego W Tarnobrzegu.

Meyskens, M., \& Bird, L. (2015). Crowdfunding and Value Creation. Entrepreneurship Research Journal, 5(2), 155-166. 
INTERNATIONAL JOURNAL OF ACADEMIC RESEARCH IN BUSINESS AND SOCIAL SCIENCES

Vol. 10, No. 7, July, 2020, E-ISSN: 2222-6990 @ 2020 HRMARS

Mukhtar, S. M. (2002). Differences in Male and Female Management Characteristics: A Study of Owner-Manager Businesses. Small Business Economics, 18(4), 289-310.

Nesta. (2012). An Introduction to Crowdfunding. Retrieved from Https://Www.Ecommercewiki.Org/Reports/655/An-Introduction-To-Crowdfunding

Nimalathasan, B. (2008). A Relationship Between Owner-Manager's Characteristic and Business Performance. Lex Et Scientia International Journal, 15, 61-68.

Ordanini, A., Miceli, L., Pizzetti, M., \& Parasuraman, A. (2011). Crowd-Funding: Transforming Customers into Investors Through Innovative Service Platforms. Journal of Service Management, 22(4), 443-470.

Piva, E., \& Rossi-Lamastra, C. (2018). Human Capital Signals and Entrepreneurs' Success in Equity Crowdfunding. Small Business Economics, 51(3), 667-686.

Protogerou, A., Caloghirou, Y., \& Vonortas, N. S. (2017). Determinants of Young Firms' Innovative Performance: Empirical Evidence from Europe. Research Policy, 46(7), 1312-1326.

Raposo, M., Do Paço, A., \& Ferreira, J. (2008). Entrepreneur's Profile: A Taxonomy of Attributes and Motivations of University Students. Journal of Small Business and Enterprise Development, 15(2), 405-418.

Rhodes, J., Cheng, V., Sadeghinejad, Z., \& Lok, P. (2018). The Relationship Between Management Team (TMT) Metacognition, Entrepreneurial Orientations and Small and Medium Enterprises (Smes) Firm Performance. International Journal of Management Practice, 11(2), 111-140.

Roma, P., Petruzzelli, A. M., \& Perrone, G. (2017). From the Crowd to The Market: The Role of RewardBased Crowdfunding Performance in Attracting Professional Investors. Research Policy, 46(9), 1606-1628.

Roth, J., Schar, F., \& Schopfer, A. (2019). The Tokenization of Assets: Using Blockchains for Equity Crowdfunding. Available at SSRN 3443382.

Sajilan, S., Hadi, N. U., \& Tehseen, S. (2015). Impact of Entrepreneur's Demographic Characteristics and Personal Characteristics on Firm's Performance Under the Mediating Role of Entrepreneur Orientation. Review of Integrative Business and Economics Research, 4(2), 3652.

Sambharya, R. B. (1996). Foreign Experience of Top Management Teams and International Diversification Strategies of US Multinational Corporations. Strategic Management Journal, 17(9), 739-746.

Shepherd, D. A., \& Patzelt, H. (2011). The New Field of Sustainable Entrepreneurship: Studying Entrepreneurial Action Linking "What Is to Be Sustained" With "What Is to Be Developed". Entrepreneurship Theory and Practice, 35(1), 137-163.

Signori, A., \& Vismara, S. (2016). Returns on Investments in Equity Crowdfunding. Retrieved from Https://Papers.Ssrn.Com/Sol3/Papers.Cfm?Abstract_Id=2765488

Sirmon, D. G., \& Hitt, M. A. (2003). Managing Resources: Linking Unique Resources, Management, And Wealth Creation in Family Firms. Entrepreneurship Theory and Practice, 27(4), 339-358.

Skirnevskiy, V., Bendig, D., \& Brettel, M. (2017). The Influence of Internal Social Capital On Serial Creators' Success In Crowdfunding. Entrepreneurship Theory and Practice, 41(2), 209-236.

Spence, M. (1973). Job Market Signalling. The Quarterly Journal of Economics, 87(3), 355-374.

Spence, M. (2002). Signalling in Retrospect and The Informational Structure of Markets. American Economic Review, 92(3), 434-459.

Storey, D. J. (1994). Understanding the Small Business Sector. Routledge. 
INTERNATIONAL JOURNAL OF ACADEMIC RESEARCH IN BUSINESS AND SOCIAL SCIENCES

Vol. 10, No. 7, July, 2020, E-ISSN: 2222-6990 @ 2020 HRMARS

Swart, R., \& Milner, M. E. (2015). Crowdfunding: A Roadmap for Global Solution Networks. Global Solutions Network.

Tanveer, M. A., Akbar, A., Gill, H., \& Ahmed, I. (2013). Role of Personal Level Determinants in Entrepreneurial Firm's Success. Journal of Basic and Applied Scientific Research, 3(1), 449-458.

Tihanyi, L., Ellstrand, A. E., Daily, C. M., \& Dalton, D. R. (2000). Composition of The Top Management Team and Firm International Diversification. Journal of Management, 26(6), 1157-1177.

Troise, C. (2019). Marketing Strategies in Equity Crowdfunding: A Comparative Study of Italian Platforms. International Journal of Marketing Studies, 11(4).

Tuomi, K., \& Harrison, R. T. (2017). A Comparison of Equity Crowdfunding in Four Countries: Implications for Business Angels. Strategic Change, 26(6), 609-615.

Turturea, R., Jansen, J., \& Verheul, I. (2015). TMT Improvisation, Resource Management and SME Performance: A Mediated Model. Frontiers of Entrepreneurship Research, 35(9), 218-223.

Vanevenhoven, J., Winkel, D., Malewicki, D., Dougan, W. L., \& Bronson, J. (2011). Varieties of Bricolage and The Process of Entrepreneurship. New England Journal of Entrepreneurship, 14(2), 53-66.

Walthoff-Borm, X., Vanacker, T. R., \& Schwienbacher, A. (2017). Equity Crowdfunding: First Resort or Last Resort? Academy of Management Proceedings, 2017(1).

Wang, T. C., \& Chen, M. F. (2016). Research of Integrating RBV And TCE To Explore Outsourcing Decision Of TMT. International Journal of Economics, Finance and Management Sciences, 4(6), 378-383.

Welmilla, I., Weerakkody, W. A. S., \& Ediriweera, A. N. (2011). The Impact of Demographic Factors of Entrepreneurs on Development of Smes in Tourism Industry in Sri Lanka. Faculty of Commerce and Management Studies, University of Kelaniya, Sri Lanka.

Xu, J., Yun, K., Yan, F., Jang, P., Kim, J., \& Pang, C. (2019). A Study on the Effect of TMT Characteristics and Vertical Dyad Similarity on Enterprise Achievements. Sustainability, 11(10), 2913.

Zheng, H., Li, D., Wu, J., \& Xu, Y. (2014). The Role Multidimensional Social Capital in Crowdfunding: A Comparative Study in China And US. Information and Management, 51(4), 488-496.

Zolin, R. (2015). Older Entrepreneurs: Do They Work Smarter or Harder? Proceedings of The Australian Centre for Entrepreneurship Research Exchange Conference, 1091-1103. 